\title{
Medical Student's Perception of Online Learning in Tadulako University During COVID-19 Pandemic
}

\author{
David Pakaya $^{1 *}$, Vera Diana Towidjojo ${ }^{2}$, Indah Puspasari Kiay Demak ${ }^{3,4}$ \\ ${ }^{1}$ Histology Department, Medical Faculty, Tadulako University \\ ${ }^{2}$ Parasitology Department, Medical Faculty, Tadulako University \\ ${ }^{3}$ Public Health Department, Medical Faculty, Tadulako University \\ ${ }^{4}$ Medical Education Unit, Medical Faculty, Tadulako University \\ *Corresponding author. Email: davidpakaya@ymail.com
}

\begin{abstract}
The online system applied during this pandemic changes the interaction pattern between lecturers and students and will affect the learning environment. Therefore, researchers are interested in knowing students' perceptions while participating in online culture in terms of their interactions and learning environment. This was a cross-sectional descriptive design. The subjects of this study were undergraduate medical students of the Tadulako University who attended online lectures during the Covid-19 pandemic from March to June 2020. 214 first to third-year students took part in this survey. The questionnaire consisted of 22 questions, which were divided into two parts, namely 10 questions for student interactions and 12 questions for learning environment. The perception between lecturers and students and students between students has not satisfying, as well as the learning environment. Therefore, to solve the problems, the institution has to create a well-organized online learning method and strengthen the role of lecturers in engaging students in the learning process.
\end{abstract}

Keywords: medical students, online learning, environment, students interaction

\section{INTRODUCTION}

Coronavirus diseases-19 (Covid-19) is a viral infectious disease that is developing so fast that it has become a pandemic. This pandemic has a serious impact on almost all aspects of human life, including education. This condition forces changes in life patterns [1]. One of the strategies used is to maintain physical distance and contact. This is intended to avoid exposure to the virus so that it can break the chain of transmission. The implementation of this strategy applies nationally through the health protocol issued by the Indonesian government [2].

Tadulako University is an educational institution that has been affected by the Covid- 19 pandemic. Referring to the circular of the Minister of Education and Culture of the Republic of Indonesia, the education process in tertiary institutions is still implemented by strictly implementing health protocols. Distance learning is an option so that the teaching and learning process continues and health protocols are applied. The transition of distance learning which was carried out during this pandemic took place very quickly so that the preparation of supporting facilities was not optimal. This learning system is a new thing for students at Tadulako University including the Faculty of Medicine. The Faculty of Medicine at Tadulako University implements online learning. The online system applied during this pandemic changes the interaction pattern between lecturers and students and will affect the learning environment. Therefore, researchers are interested in knowing students' perceptions while participating in online culture in terms of their interactions and learning environment [3], [4]. 


\section{METHODS}

This study used a Likert scale survey method, through online questionnaires. This was a crosssectional descriptive design. The subjects of this study were undergraduate medical students of the Tadulako University who attended online lectures during the Covid-19 pandemic from March to June 2020. 214 first to third-year students took part in this survey, out of a total of 390 undergraduate students who were actively involved in academic activities in the form of online lectures and practicum. Which means the response rate of the questionnaire was $55 \%$. The number of the participants, which is more than half of the population, has met the requirements to generalize the survey results. The data obtained was presented in tabular form and analyzed descriptively quantitatively by presenting the percentage of each response to each of the questions. The questionnaire was modified based on [5] which consisted of 22 questions. This questionnaire is divided into 2 parts, namely students 'perceptions of student interactions in online learning, there are 10 questions and students' perceptions of the learning environment in online lectures there are 12 questions.

\section{RESULTS AND DISCUSSION}

The results of the questionnaire obtained are as follows.

\subsection{Students perceptions of student interaction in online learning}

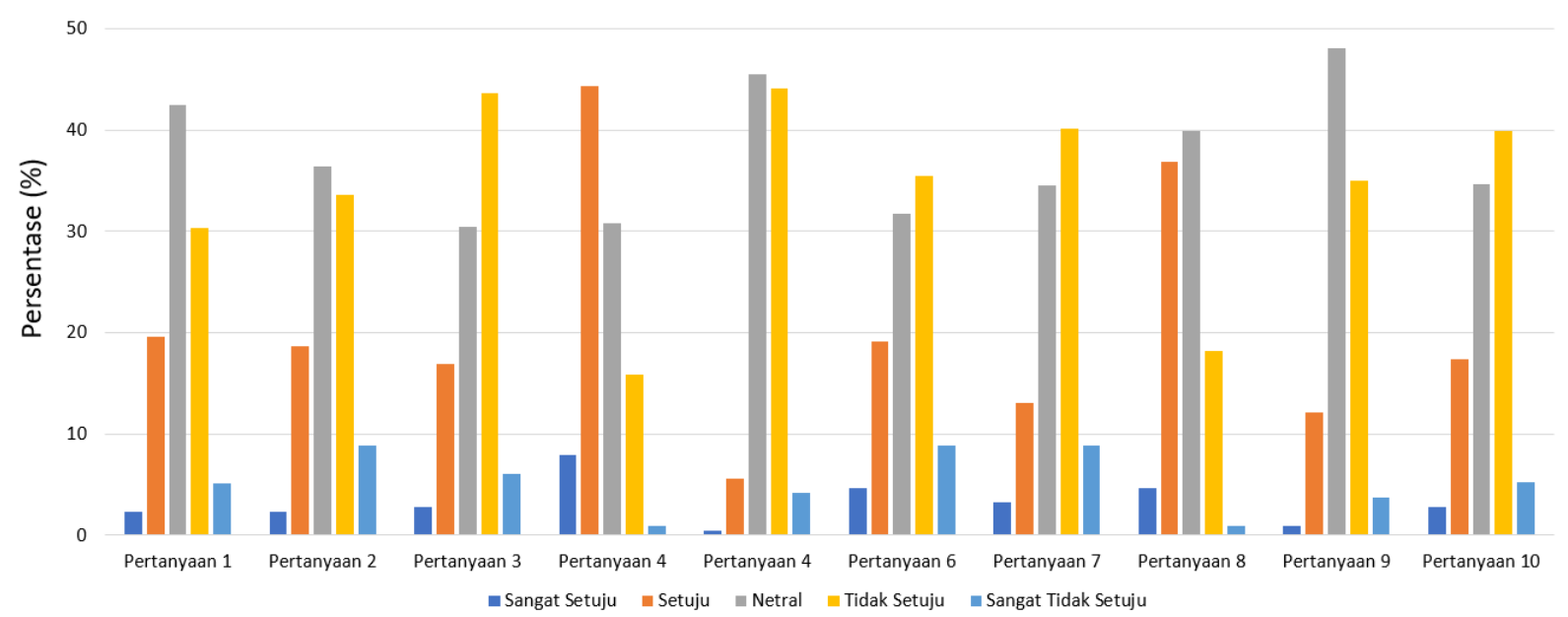

Figure 1. Students' perceptions of student interactions in online learning

1. Online lectures make it easier for me to interact with lecturers. There are $42.5 \%$ of students who are neutral, $30.4 \%$ who disagree and $5.1 \%$ strongly disagree and $19.6 \%$ of students agree. This illustrates that the direct relationship between lecturers and students is very important to build communication in the learning process.

2. Interaction with lecturers is easier to get familiar with online lectures. $36.4 \%$ of students were giving neutral responses and $33.6 \%$ disagreeing and $18.7 \%$ agreeing. This means that in online lectures, students will find it more difficult to get along with lecturers. This is due to the absence of face-to-face contact between students and lecturers, so that interaction is minimal. Online lectures will be maximized if followed by face- toface to maximize communication between lecturers and students [6].

3. Expressing the problems faced in lectures to lecturers is more comfortable online than face to face. There were $16.9 \%$ who agreed, but most students or 43.7\% experienced problems communicating their lecture problems to the lecturers. This is an obstacle in the learning process if the problems in lectures cannot be resolved through this online system.

4. Miscommunication between lecturers and students is more common in online lectures. 
There were $44.4 \%$ of students responding agreeing that miscommunication between lecturers and students often occurs. The language of written communication via electronic mail or other communication devices (for example WhatsApp, LINE) is indeed more difficult to understand. [7] mention different things; with an online system the ability to consult is actually better and supports learning more effectively. Miscommunication that occurs will result in different interpretations so that the learning objectives cannot be achieved [2].

5. Collaborating with lecturers such as joint research, joint committee members, and so on is more common in online lectures. There are $45.5 \%$ of students neutral towards this statement, and $44.1 \%$ disagree. This online lecture system turns out to make it difficult for students to build collaboration and cooperation in conducting research, community service, and other development activities.

6. Online lectures make it easier for me to interact with fellow students. There are $35.5 \%$ disagree with this statement, and only $19.2 \%$ agree. These results show that there are difficulties in interacting with students and lecturers, students also have difficulty interacting with others so that it can affect the teaching and learning process.

7. Interaction with fellow students is easier to get acquainted with online lectures. There are $40.2 \%$ of students who disagree with this statement, and only $13.1 \%$ agree. This illustrates that the difficulty of student interaction through this online system makes it difficult for students to be close to each other.

8. Miscommunication among students is more common in online lectures. There were $39.3 \%$ of students who answered neutral to this question, but there were $36.9 \%$ who agreed with the statement. This indicates that there is frequent miscommunication between students during online lectures.

9. Collaborating with fellow students such as conducting joint research is more common in online lectures. There were $48.1 \%$ who answered neutral, but $35 \%$ disagreed with this statement and only $12.1 \%$ agreed. This can indicate that students have difficulty collaborating with other students. The difficulty of collaboration between students can have an impact on working on assignments as a group; the effect is that efforts to form students who can work in teams will experience obstacles.

10. Solving problems among fellow students is easier in online learning. There are $17.4 \%$ of students agree with this statement, but most students or $39.9 \%$ disagree. This indicates that in online lectures students have difficulty solving their problems.

From the description of the results of the questionnaire above, it can be said that in online lectures students have difficulty interacting and collaborating with lecturers and others. Interaction and collaboration are enthusiasts in learning so that learning outcomes can be better. Students also find it easy to have miscommunication between each other or with the lecturer. Communication is an important factor in the success of learning because it is able to open the widest possible question and answer space for various matters related to learning [8]. If these things are not carried out properly, they can become obstacles in the learning process [2].

The role of lecturers in engaging students in the learning process is an important factor required so that the interactions that occur run well. So that what is expected, namely students can receive material optimally can occur. Online learning is something new in the Medicine Study Program at Tadulako University. So that lecturers need to get special training on how to make online lectures more effective. One of them is by knowing how to engage students so that they can be more focused and interested in ongoing lectures. In online courses, students often feel less supervision from lecturers. This can be overcome by recording the lecturer always taking an oral test at the end of the lecture. Especially for practicum, lecturers can give specific feedback to some students who feel they are still lacking in performance. [9]-[11] 


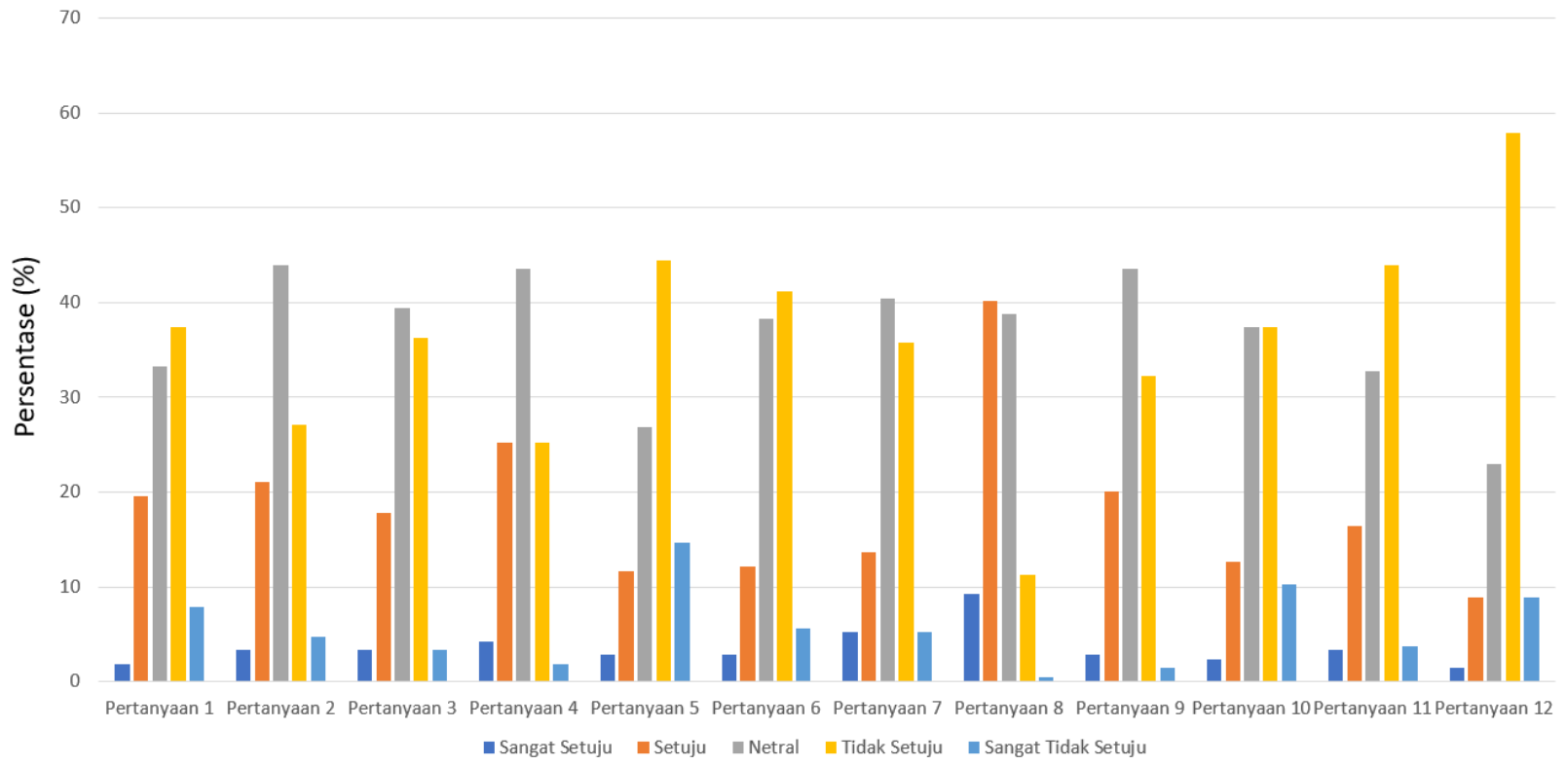

Figure 2. Student perceptions of the learning environment in online learning

\subsection{Students perceptions of the learning environment in online learning}

1. An online learning environment helps me understand learning material more easily. This statement received a $37.4 \%$ disagreement response, and only $19.6 \%$ agreed. Students find it difficult to understand the material if it is only submitted online. This can occur due to miscommunication problems and the learning environment of this online system does not support the learning atmosphere. Students who do not meet directly with their lecturers may misinterpret material explanations or cannot capture material explanations due to meeting access and internet networks and limited time [12].

2. The learning environment in online lectures awakens me to study harder to understand the material. There are $43.9 \%$ of students who respond neutral, but $27.1 \%$ disagree and $21 \%$ agree. This illustrates that many students have not yet determined their attitude in assessing themselves whether they are active or not to learn to use this system. There are more students who are not active than those who are active in studying through online lectures.

3. A learning environment in online lectures that encourages me to take online courses. This question received a neutral response of $39.4 \%$ and $36.2 \%$ disagree and disagree. These results indicate that the neutral choice of students indicates that online lectures are not carried out as an option but as a necessity. Students who disagree are more than those who agree, meaning that the decision to follow the online system lectures is not based on the expected learning environment.

4. I feel comfortable answering the questions given in online lectures. This question received a neutral response of $43.5 \%$, and the answers to agree and disagree were balanced. The neutral response of most students is understandable because it depends on the questions asked.

5. I prefer the learning environment for online lectures rather than face-to-face. Most of the students responded disagree which reached $44.1 \%$ and $14.6 \%$ strongly disagreed. This may imply that a face-to-face learning environment is more enjoyable than an online system.

6. I took online courses because I liked the learning environment. This question was responded to by students who disagreed as much as $41.1 \%$, neutral $38.8 \%$, and agreed $12.1 \%$. From this data, it is known that online lectures conducted by students are not an option because this system supports their lectures, but rather a necessity due to the pandemic. 
7. The learning environment in online lectures greatly contributes to my satisfaction with learning. Most of the students responded to this question, namely 40.4\%. Meanwhile, $35.7 \%$ of students disagreed and only $13.6 \%$ agreed.

8. I prefer to respond to questions in person rather than online. This question was most responded to agree, reaching $40.2 \%$ of the total students, $38.8 \%$ answered neutral and 9.3\% answered strongly agree.

9. The learning environment in online lectures makes it easier for me to find my learning needs. As many as $43.5 \%$ of students responded neutral, $32.2 \%$ disagreed, and $20.1 \%$ agreed. This is because students have difficulty discussing problems when learning with an online system. After all, they are limited by distance and network.

10. I suggest that more lectures be held online because the learning environment is fun. This question was responded to by $37.4 \%$ neutral and $37.4 \%$ disagree. This is felt because there are several courses, laboratory practicums, and clinical skills that are difficult to do online.

11. The learning environment in online lectures makes it easier for me to solve the learning problems I face. A total of $43.9 \%$ disagreed, $32.7 \%$ were neutral and $16.4 \%$ agreed. Online lectures will be maximized if accompanied by face-to-face [6].

12. It makes no difference to me the learning environment in online and face-to-face lectures. This question was responded to by $57.9 \%$ of students who disagreed and $22.9 \%$ who were neutral. This means that the environment of the two learning methods is very different.

The learning environment has a very important role in the learning process. It takes a learning environment with a comfortable atmosphere to arouse students' enthusiasm for learning. The results illustrate that students' perceptions of the online learning environment at the Faculty of Medicine, University of Tadulako, have not provided maximum support for learning. Many factors influence the quality of this online learning environment.

The learning environment is related to student satisfaction. Good learning environments, such as well-organized classrooms and opportunities for group affiliation are the highest correlated dimensions of the learning environment in terms of student confidence in the successful completion of studies. Student satisfaction and confidence will increase automatically in learning situations, and this need is considered. The presence of teacher support, the connection between students, the change of active student involvement, a good level of task orientation, and well-organized learning activities are important things to be considered to develop a good learning environment in online learning.[2]

\section{CONCLUSION}

The perception of medical students of Tadulako University about online learning during the Covid-19 pandemic in terms of interactions, both between lecturers and students and between students, has not gone well. In terms of the learning environment, online lectures have not provided the maximum in supporting the teaching and learning process.

However, the online learning process is the only option in implementing academic activities during the Covid-19 pandemic. Therefore, to solve the problems, several things need to be done. First, creating a well-organized online learning method, for example by making guidelines and specific regulations for academic activities online and disseminating it to lecturers and students, strengthening the support of educational staff in arranging the schedule, and providing supporting infrastructure from the faculty. Second, strengthening the role of lecturers in engaging students in the learning process.

\section{REFERENCES}

[1] Zaharah, galia ildusocna Kirilova, and A. Windarti, "Dampak Wabah Virus Corona Terhadap Kegiatan Belajar Mengajar di Indonesia," Salam J. Sos. dan Budaya Syar'i, vol. 7, no. 3, pp. 269-282, 2020, doi: $10.15408 /$

sjsbs.v7i3.15104.

[2] E. Daroedono et al., "The impact of COVID-19 on medical education: our students perception on the practice of long distance learning," Int. $J$. Community Med. Public Heal., vol. 7, no. 7, p. $2790, \quad 2020, \quad$ doi: $\quad 10.18203 / 2394-$ 6040.ijcmph20202545.

[3] M. N. Ferrel and J. J. Ryan, "The Impact of 
COVID-19 on Medical Education," Cureus, vol. 12, 10.7759/cureus.7492.

$$
\text { no. 3, pp. 10-13, 2020, doi: }
$$

[4] S. Rose, "Medical Student Education in the Time of COVID-19," JAMA - J. Am. Med. Assoc., vol. 323, no. 21, pp. 2131-2132, 2020, doi:

10.1001/jama.2020.5227.

[5] N. Adijaya and L. P. Santosa, "Persepsi Mahasiswa dalam Pembelajaran Online," Wanastra, vol. 10, no. 2, pp. 105-110, 2018, doi:

2579-3438.

[6] T. Almarabeh, "Students' perceptions of E- learning at the University of Jordan," Int. J. Emerg. Technol. Learn., vol. 9, no. 3, pp. 31-35, 2014, doi: 10.3991/ijet.v9i3.3347.

[7] E. Warnecke and S. Pearson, "Medical students' perceptions of using e-learning to enhance the acquisition of consulting skills," Australas. Med. J., vol. 4, no. 6, pp. 300-307, 2011, doi: 10.4066/AMJ.2011.73.

[8] K. R and M. Vinayak Mahajan, "A study of students' perception about e-learning," Indian J. Clin. Anat. Physiol., vol. 5, no. 4, pp. 501-507, 2018, doi: 10.18231/2394-2126.2018.0116.

[9] W. A. Org, R. Ellaway, K. Masters, and R. H. Ellaway, "AMEE Guides in Medical Education eLearning in Medical Education Teaching and Learning e-Learning in Medical Education Part 1: Learning, teaching and assessment Part 2: Technology, management and design The Authors eLearning in Medical Education,” 2008.

[10] I. Yengin, D. Karahoca, A. Karahoca, and A. Yücel, "Roles of teachers in e-learning: How to engage students \& how to get free e-learning and the future," Procedia - Soc. Behav. Sci., vol. 2, no. 2, pp. 57755787, 2010, doi: 10.1016/j.sbspro.2010.03.942.

[11] N. D. @ Omar, H. Hassan, and H. Atan, "Student Engagement in Online Learning: Learners Attitude Toward E-Mentoring," Procedia - Soc. Behav. Sci., vol. 67, no. November 2011, pp. 464-475, 2012, doi: 10.1016/j.sbspro.2012.11.351.

[12] D. O'Doherty, D. Marie, L. Justan, and D. M. D. Ailish Hannigan, Last Jason, "Barriers and solutions to online learning in medical education-an integrative review," BMC Med. Educ., vol. 18, no. 130, pp. 113, 2018, doi: https://doi.org/10.1186/s12909-0181240-0. 